in the Food Controller's offices for some time past, and the confusion of thought on the question of what cost of production really is which these discussions have revealed is evidence of the need for study and education in costing processes. Few things can be of greater service to the farmer than scientific book-keeping carried out and interpreted with proper understanding, but few things can deceive him more than costing wrongly conducted or misinterpreted.

Lastly, I want to urge, and particularly before a gathering such as this, the importance of agricultural economics in agricultural education. The fact is realised, no doubt, by many teachers, but until a sufficient body of data bearing on the study of farm management can be made available to them it is impossible for them to give to the teaching of practical agriculture that solid economic basis which is fundamental, and the teacher is driven to include in his instruction much to which the economic test has never been applied and to exclude more for which no basis for teaching exists at all. Given the requisite body of information. it would not only be possible but also necessary to recast the whole foundations upon which the teaching of practical agriculture rests.

\title{
Black Coral as a Charm for Rheumatism.
}

\author{
By Prof. J. Stanley Gardiner, F.R.S.
}

$\mathrm{M}^{\mathrm{R}}$ R. C. H. POWNALL, of Banjoewangi, Java, has sent to NATURE office a letter accompanying three bracelets made from the horny skeletal substance of a soft coral or Gorgonian, known to science as Plexaura. This forms great branched growths which are abundant on the outer or seaward sides of coral reefs at from 1o to 40 fathoms, but in protected situations almost reaching the surface. All corals are formed by anemones, and the one in question here possesses eight feathered tentacles round the central mouth. The original anemone of a "colony," as the whole animal is termed, settles on the bottom and buds off other anemones from its sides; these in turn giving birth to further children. All remain attached to one another by canals, so that the whole growth forms a single, many-mouthed animal. It takes the form of long branches, the whole simulating a broom-like shrub growing upon the bottom of the sea. The skeleton is in the centre of the stems, and consists of an axis of black, horny substance in each branch, surrounded by the living tissues of the anemones, these further strengthened by scattered spicules of carbonate of lime. Generally, the branches are regarded as bèlonging to some form of submarine plant, to which the name Akar Bahar is given in the Malay Archipelago.

The bracelets, which are the cleaned, horny axes of stems twisted into rings, are "credited with the virtue of curing rheumatism." "There are," says Mr. Pownall, "many doctors in the Malay Archipelago who advise their patients to make use of them. They acknowledge that the bracelets do good, although they cannot account for it. It has been suggested that the substance is radio-active. Personally, I can testify that, during a residence of forty-seven years in this part of the world, I have never met a person who has used one of these bracelets without deriving benefit from it. The bracelets are usually worn on the left arm. All natives are firmly convinced of their efficacy, and all seamen and others who are much exposed to the wet make use of them. They maintain that they must be ursed quite plain; any ornamentation of gold or silver renders them useless."

Rheumatism is, of course, one of those diseases which can have as many causes as there are weeks in the year. Any concretions in any part of the body, however caused, may give the regular symptoms. The close association of rheumatism with malaria is well known to every tropical traveller, and malaria is particularly rife among coast-dwelling people. In some cases the symptoms described by the malarial patient are such as are usually associated with rheumatism. The present writer, while living in a small tropical island, Rotuma, ran out of quinine, which he had found quite effective. His reputation, however, had been established by that time, and he then found a mixture of cascara, brown sugar, and methylated spirit equally good. Probably these bracelets, if he had had them, would have been quite effective to produce similar faith cures. They exhibit absolutely no trace of radio-activity, and are not composed of a substance which could produce any direct effect. A lady who is a victim to rheumatism has worn one of these bracelets for a month, with considerable comfort and a satisfaction which she herself laughs at.

The association of the bracelets with rheumatism in the Malay Archipelago is interesting, because the use of similar bracelets merely as articles of adornment seems to be widely spread among. fisherfolk from Suez to the most distant islands of the Pacific. They are made either of the stems of some Gorgonian such as the above, or of the true black coral (Antipatharia), in which the central horny rod is slightly hollowed. In the Maldives, growths dredged up by the present writer, after he had taken what he required, were eagerly divided up by his native crew, and a large piece was taken by the Sultan's representative to be presented on his return to court. The ornaments made were exclusively used by the women. Other coloured Gorgonians obtained at the same time were quite neglected. One of the black sailors, originally recruited at Zanzibar, on

NO. 2720 , VOL. IO8] 
H.M.S. Sealark in 1905 always wore a pendant of black coral under his blouse, and all the black "boys" on board begged pieces from us "to keep them from drowning." Inquiries show, too, that black ornaments, bracelets, rings, and pieces strung into necklets are common on all coasts from Zanzibar to Singapore. They are usually described as wood, but, as it is stated that the ends overlap or that the bracelets or rings are spiral, they are probably of coral. A Japanese professor says that black coral is much valued in China and Japan, and largely used by coastal people for jewelry. Branched growths are not infrequently brought up on the hook when fishing outside coral reefs, but, while there are frequent indications of local use, there is no regular fishery for such as an article of commerce.

Rheumatism would seem to be particularly a "charm" disease. All over England a potato is carried in the pocket as a remedy, and several ladies residing in Cambridge derive great benefit from the permanent presence of horse chestnuts below their couches. Rings of metal-tin in many parts of the West-are a regular specific. One of the black bracelets in question has a decorative value of its own. We wonder, however, whether the ladies might not find Chinese jade a still better specific.

\section{Obituary.}

\section{J. M. Dodds.}

RY the death of John Macalister Dodds on November I 3 last Cambridge has lost a great gentleman, while many people, both inside his college and outside, have lost a most kindly, helpful, and amusing friend. He took his degree as fifth wrangler in $\mathrm{r} 88 \mathrm{I}$, and returned from Glasgow to Peterhouse as bursar and mathematical lecturer in 1884 , since when he had resided in college continuously. He lectured, as usual, on November 12, and was found dead in his chair the following morning. Apparently the only published paper he was connected with was one on the value of the B.A. unit of resistance (R. T. Glazebrook and J. M. Dodds, Phil. Trans., 1883 ).

On returning to Cambridge $\mathrm{Mr}$. Dodds gave advanced lectures on the theory of sound for some years, in addition to his routine work, but henceforth his main interest lay in the theory of numbers, the theory of groups, and kindred topics. Particularly was he interested in the theory of numbers, and he worked at it incessantly. I have heard him say that he tended to lose interest when the continuous variable was introduced into that beautiful subject. Indications are not lacking that such feelings were shared by Gauss himself, but in reality the leaning of Mr. Dodds was towards ancient, simply stated, and difficult problems of a pre-Gaussian kind. $\mathrm{He}$ was extraordinarily astute, for example, in the application of Fermat's famous principle of infinite descent. Formal algebra, too, had a great fascination for him.

A word must be said of his generosity in working at a problem with a colleague; the algebraical avenue being left to him, Mr. Dodds was untiring in his efforts until the inquiry became hopeless or the question was determined. One habit of his is probably now obsolete; each long vacation he made a complete set of solutions of the Tripos papers that had just appeared. Younger generations do not, I think, regard that as being any longer a task that provides mental exhilaration, even supposing the problems come out.

This is not the place to dilate on the wide knowledge of books and human beings that vast reading and irresistible social powers had given Mr. Dodds, yet no account of him can be complete without an allusion to what was, it may be, the most marked feature in his attitude on general questions. He was an intense and innate conservative; the smallest sug gestion of change always seemed to arouse his instant opposition. As he was an acute dialectician, this might easily have become exasperating, but he was so big, so strong, and so laughingly goodnatured that the almost inevitable did not happen. If he sometimes laughed at others, he often laughed at himself.

J. H. G.

WE regret to announce the deaths, on December 9, of LORD LINDLEX at the age of ninety-three years, and, on December II, of LORD HALSBURY at the age of ninety-eight years. Both were elected fellows of the Royal Society under the special clause which permits the admission of members of the Privy Council-Lord Lindley on January 20, 1898 , and Lord Halsbury on January $x_{3}, 1887$. It may be recalled that Lord Lindley was the son of the late Dr. John Lindley, professor of botany in University College, London.

\section{Notes.}

ON Saturday, December Io, the Official Referee under Part I. of the Safeguarding of Industries Act gave his decision on the complaint that santonin has been improperly included in the list of goods upon which import duty must be paid. The drug is derived from flowers grown almost exclusively in Southern Russia and Turkestan, and is extracted by a simple process which does not appear to demand professional skill ; its application is medicinal as distinguished from chemical, but the evidence on the question whether it should be regarded as a "fine chemical" was most conflicting, and emphasised the difficulty which may be experienced in defining a "synthetic organic chemical" within the meaning of the Act. After two hearings Mr. Cyril Atkinson, K.C., expressed the view that the word "chemical" is not a scientific term, but implies a

No. 2720 , VOL. IO8] 